\title{
CIVIL WAR IN THE KINGDOM OF BENIN, 1689-1721: CONTINUITY OR POLITICAL CHANGE?
}

\author{
BY PAULA BEN-AMOS GIRSHICK \\ Indiana University \\ AND JOHN THORNTON \\ Millersville University
}

ABSTRACT: Using a combination of oral tradition and written documents, the authors show that Benin's civil war was a fundamental transformation of political structure, and not simply an isolated struggle. Before 1640 , Benin was centrally governed by its king with the assistance of a royally appointed administration. Difficulties in succession, coupled with changing trading patterns, allowed the administration to gain some independence and then to challenge the kings, taking away some power. The civil war matched different levels of the administration and the kings against each other, and transformed Benin from a centrally governed to a more collectively governed kingdom.

KEY WORDS: Benin Kingdom, western Africa, kingdoms and states, precolonial.

TowarDs the end of the seventeenth century, ${ }^{1}$ a number of European observers noted that the Edo Kingdom of Benin ${ }^{2}$ had been racked for some years by civil war. One of the longest accounts, that of David van Nyendael, reported that as a result of this civil war, Benin City had been sacked and in his day (I699-I 70I) was reduced to a 'mere village'. ${ }^{3}$ Apparently beginning shortly before 1690,4 the civil war stretched on well into the eighteenth

1 The authors wish to thank Phyllis Martin for her helpful comments, William Hart for bringing the Stanfield reference to their attention, and the Ihama of Ihogbe for sharing his knowledge of royal history.

2 While in the documents the kingdom is called 'Benin', 'Benijn' or 'Benym', today the people call themselves, their language and their capital city 'Edo'.

3 William Bosman, Naukeurige beschryving van de Guinese Goud-Tand-en Slave Kust (Utrecht, I 704), 250, 255-6. This text gives the date of David van Nyendael's letter, which Bosman prints verbatim, as I Sept. I 70 I. The well known English translation, $A$ New and Accurate Description of the Coast of Guinea Divided into the Gold, the Slave and the Ivory Coasts (London, I 705, modern facsimile reedition with introduction by John Ralph Willis and notes by J. D. Fage and R. E. Bradbury, London, 1967), 468, gives the date as I Sept. I 702. As the translation is often faulty, we have made use of the original and in some cases retranslated passages in quotations.

4 The Benin historian, Jacob U. Egharevba, placed these events in the reign of Ewuakpe, which he dated to about I 700 ( $A$ Short History of Benin [4th ed., Ibadan, I 968 ], 37) but R. E. Bradbury proposed on the basis of his reading of van Nyendael's account that the events must have started about I690 (R. E. Bradbury, 'Chronological problems in the study of Benin history', reprinted in Benin Studies, ed. Daryll Forde [Oxford, I 973], 28-30). Further evidence on the early date is also provided by documents from the Archives of the Propaganda Fide in Rome analyzed by A. F. C. Ryder, Benin and the Europeans, I485-1897 (London, I 969), I $14-9$, especially Archivo 'De Propaganda Fide' Scritture riferite nel Congressi (henceforward abbreviated APF: SRC), Congo 3, fols. I37-38, Francesco da Monteleone to Propaganda Fide, 4 Sept. I6g6. 
century. Although a terminal date for the civil war period is difficult to define, the crisis situation seems to have been passed about mid-way through the reign of the Oba (king) who died in $1735 .{ }^{5}$ This Oba's report to Dutch merchants at the port village of Ughoton in 1721 that his army had routed a rival probably represents the turning point in the war. ${ }^{6}$ From European accounts and oral traditions, it is possible to show that this civil war was an important turning point in Benin history.

The first serious elaboration of Benin history by the Edo historian Jacob U. Egharevba relied mostly on the oral sources that he had access to in the I 930 , although he was aware of, and made use of, some older documentary sources as well. " In his assessment, the civil war period was a temporary setback for the monarchy, resulting primarily in the loss of territory and a short-range reduction in the splendor of the city, both of which were largely restored during the reign of the victorious Oba Akenzua I. Benin only truly declined in the nineteenth century. The history of Benin was extensively reexamined after 1956, when the University of Ibadan began the Scheme for the Study of Benin History and Culture, which brought together historian Alan Ryder, who examined Benin history in European archives, and social anthropologist R. E. Bradbury, who conducted extensive field research. Although they produced important modifications in historical details and chronology, both scholars in their various publications accepted the general outlines of Benin history as Egharevba laid them down. ${ }^{8}$

In re-examining the question, however, we will propose a different interpretation, which sees the civil war as an important turning point in Benin's history. We will contend that as a result of this war significant structural changes took place in the political system of Benin that resulted in a substantial loss of royal centralization and a fundamental reorganization of the state, transforming it from an autocratically ruled polity to one where decision making and power were much more diffused among groups with aristocratic and mercantile origins. Whatever temporary loss of external power occurred was an understandable but secondary effect. This transformation was linked to a shift in trade relations from ivory and pepper,

5 Egharevba, Short History, 39 supplies the probable name of this Oba-Akenzua I - whose death in 1735 is documented by Ryder in Benin and the Europeans, 192.

${ }^{6}$ Algemeen Rijksarchief (The Hague), Nederlands bezittingen ter Kust Guinea (henceforward abbreviated ARA: NBKG) 88, Elmina Journal, 25 Oct. 1721, Jacobos Munnickhoven to William Butler, 20 Jan. 1721. Letters from the Dutch factors in Ughoton, Benin's port, to their headquarters found in this archive were recorded in the Elmina Journal, a diary kept by the Director at the Dutch West India Company's headquarters at Elmina on the date they were received. In citing this material, we have included both the date of the entry in the Elmina Journal (as the journal is often unpaginated) and the date of the letter itself. Ryder, who also made use of this material and quoted it extensively, did not include the Elmina Journal dates in his book, which has made his references very hard to retrace. Our research in these archives has been through the microfilm copies found in the Northwestern University Library. We found no documents that Ryder had not cited. $\quad$ Egharevba, Short History, passim.

${ }^{8}$ Ryder, Benin and the Europeans, I 8-23; R. E. Bradbury, Benin Studies, x; "The Kingdom of Benin', in Daryll Forde and P. M. Kaberry (eds.), West African Kingdoms in the Nineteenth Century (1967), reprinted in Benin Studies, 44-75. Bradbury also used Ryder's material to the 1967 reprint of the 1705 English translation of Bosman, Description. which were royally con not controlled centrally those associated with $\mathrm{m}$

The main reason th: from the way in which writings from the 193 informants, and Ryder idea that the kingdom' beginning of the colon continuity of the recent consider, but they ultir been because historian traditions than they $d$ impressed that so muc was confirmed by th unknown to him. This convinced both Ryder based version, so that $t$ seemed to diverge fro observer error. ${ }^{9}$

Our reinterpretation re-examines the raw tr sources have the adv describe and are most Alonso de Sandoval's were written by people de Sandoval by slave and Dapper by a nu survives independent eye-witnesses to wha

- Ryder, Benin and the observer error, see Brad discussed in detail below

10 Alonso de Sandova disciplina $i$ catechismo ex Valtierra as De Instaura America, (Bogota, I956) Cartagena $c .16$ ro and $t$ Dapper, Naukeurige Bes. ed., Amsterdam, 1676 , $\mathbf{1 6 7 0 )}$ and unreliable abri recent years. John Ogilby mistranslations and omi Beschrijuinge van Africe Africanus (Rotterdam, description of Africa ( $\mathrm{r}$ similar but not identica Publica Latina 927, 'Ae Africa' (edited, with pas the Mid-Seventeenth $C$ may be the work of an $e$. information. 
which were royally controlled and reinforced the kings, to cloth, which was not controlled centrally at all and tended to strengthen local associations and those associated with more independent merchants' groups.

The main reason that these structural changes have been missed stems from the way in which Benin history was represented by Egharevba in his writings from the r 930 s on. Egharevba, his informants, Bradbury, his informants, and Ryder all based their understanding of the Benin past on the idea that the kingdom's structure was essentially the same as it was at the beginning of the colonial period. The dangers of the assumption of long continuity of the recent structure were an issue that Bradbury and Ryder did consider, but they ultimately yielded to the traditions. In part this may have been because historians in the 1960 s had more faith in the literal use of oral traditions than they do today, but both Ryder and Bradbury were in fact impressed that so much of Egharevba's tradition-based version of history was confirmed by the discovery of unpublished documents completely unknown to him. This remarkable, at times even spectacular, convergence convinced both Ryder and Bradbury to continue to privilege the traditionbased version, so that they were prepared to dismiss places where documents seemed to diverge from the history presented by Egharavba's as simply observer error."

Our reinterpretation places more emphasis on documentary evidence and re-examines the raw traditional data that Egharevba used. The documentary sources have the advantage of being contemporary to the events they describe and are mostly the work of eyewitnesses. Although a few, such as Alonso de Sandoval's description (1627) or Olfert Dapper's 1668 account, were written by people outside Africa, both were informed by eye-witnesses: de Sandoval by slave-ship captains (and sometimes the slaves themselves) and Dapper by a number of Dutch merchants, some of whose writing survives independently. ${ }^{10}$ Many other accounts were indisputably those of eye-witnesses to what they described, notably those of Dierick Ruiters

- Ryder, Benin and the Europeans, $1-15$; on the issue of divergences being explained by observer error, see Bradbury's notes to the new English edition of Bosman's book, discussed in detail below.

10 Alonso de Sandoval, Naturaleza, policia sagrada $i$ profana, costumbres $i$ ritos, disciplina $i$ catechismo evangelico de todos Etiopes (Seville, I627; mod. ed. by Angel Valtierra as De Instauranda Aethiopum Salute: El Mundo de la Esclavitude Negra en America, (Bogota, 1956)), cited by pagination of modern edition. Sandoval arrived in Cartagena $c$. 1610 and the license to publish the book was obtained in 1624; Olfert Dapper, Naukeurige Beschrijuinge van Africa gewesten (Ist ed., Amsterdam, I668; 2nd ed., Amsterdam, 1676, cited here). Both the generally reliable German (Amsterdam, 1670 ) and unreliable abridged French (Amsterdam, 1676) editions have been reprinted in recent years. John Ogilby's Africa (London, I670) is a translation with a few emendations, mistranslations and omissions; other Dutch sources include Arnout Leers, Pertinente Beschrijwinge van Africa ... getrokken en vergadert uyt Reys boeken van Yohannes Leo Africanus (Rotterdam, I665), although the title implies a precis of Leo Africanus' description of Africa ( 1526 ), the material following ch. xvii, 289 et seq. is new material, similar but not identical to that in Dapper; Universitetsbibliothek Leiden, Biblioteca Publica Latina 927, 'Aenwijsingse van diversche Beschrijvingen van de Noort-Cust van Africa' (edited, with pagination of original Ms marked, by Adam Jones, West African in the Mid-Seventeenth Century [East Lansing, 1994]) which relies on various sources, but may be the work of an eyewitness as well. It too overlaps with Dapper, but has additional information. 
( 1602 ), the Capuchin missionaries of the mid-seventeenth century, David van Nyendael (1701) and the Dutch factors of Ugoton (1716-38). ${ }^{11}$

Although most of these observers resided in Benin, they were limited in their ability to see all aspects of Benin life. Benin officials were generally anxious to restrict the activities of European visitors, who were encouraged to go only where their commercial activities required. ${ }^{12}$ While this limited their ability to say much about rural life and religion, it did not limit their knowledge of political and institutional life, in which they had a vital interest and touched on their commercial practice, given that trade was by all accounts quite closely controlled by the state. ${ }^{13}$ At least one Dutch factor is known to have held a title in Benin, ${ }^{14}$ which could well have provided him with information about the structure of the kingdom.

The oral traditions present special problems which must be resolved in order to use them for our purpose. The traditions about political history that have been collected in recent times come from a small circle consisting of the $O b a$, the Ihogbe (priests and genealogists of the royal ancestors), and various titleholders and others involved in court life. All can be expected to present the royal view of the past. ${ }^{15}$ Although Egharevba's Short History of Benin is usually taken to constitute the accepted version of Benin history as preserved in oral traditions, it is in fact a history of the western sort that uses oral traditions as its fundamental primary sources. Beginning in the r93os, Egharevba assembled a vast collection of disparate oral traditions from titleholders, priests and elders in Benin, many of whom had been alive prior to the British colonial takeover in 1897 . From this collection, Egharevba then created an orderly written history addressed to a dual audience: on the one hand, he wished to present a creditable western-style history to British

11 The author of this 1602 account, D. R., is identified as Dierick Ruiters by Klaas Ratelband in his introduction to $\mathrm{P}$. van den Broecke, Reizen naar West Afrika, (The Hague, 1950), lviii-lx. The majority of the Capuchin reports are to be found in Archivio 'De Propaganda Fide' (henceforward APF), especially the series Scritture Originali refirite nell Congregazioni Generali (henceforward SOCG). A partial list is in Ryder, Benin, $149-50$, which does not include the SOCG material dated later than 1657 . In addition, see the account of Bonaventura da Firenze (ed. V. Salvadorini), Le missione a Benin e Warri nel XVII secolo : La relazione inedita di Bonaventura da Firenze (Milan, 1972). Bosman, Beschryvinge, 213-57 reproduces Nyendael's letter of Sept. I, 1701. Documentation of the Dutch factors is found in ARA: NBKG for the most part. See Ryder, Benin 350 .

${ }_{12}$ Pieter de Marees, Beschryvinge ende Historische Verhael van het Gout-Koninkirjk van Guinea (ed. S. P. L'Honoré Naber, The Hague, I gog). The pagination of the original Ms is preserved in this Dutch edition and also used in the English translation of Albert van Dantzig and Adam Jones, Historical Account of the Golden Coast of Africa (Oxford, 1989).

${ }_{13}^{3}$ General descriptions of European trade in Ryder, Benin and the Europeans, passim.

14 Abrams Raems claimed to have become a 'homme grande' a name given to titled officials. ARA: NBKG vol. 102, Raems to Hertog, 22 Oct. 1736, cited in Ryder, Benin and the Europeans, 187 .

15 Officials in the Benin government were holders of a title (egie) in the political administration. Only a few of these were hereditary (egie-asegbere). From the nineteenth century the three main groups of titleholders governing Benin have been the Uzama n'Ihinron, (Seven Uzama), the Eghaevbo n'Ogbe (palace chiefs) and the Eghaevbo $n^{\prime}$ Ore (town chiefs). The English word 'chief' is in widespread usage in Benin today, whether the speaker is using either Edo or English, and will be employed here along with the term 'titleholders'.
CIVIL WAR IN

colonial officials and we expectations of the Edo

With this audience in held in memory by $E_{\text {. }}$ circulated legends abo chronology. He workec created order. His dat remarkable that his pi supported by written : anyone else at the time

In presenting the ma omitting, for example offended British sensit minimized episodes rer unpleasant for the ro: treatment of the instal crucial issue in underst concur that upon the chronology), there wer to Egharevba, the resu different branches of traditions relating to participated in this rote successions in the $\mathrm{m}$ struggles between riv: directly in the royal lit as the Edo say, were $r$

Egharevba provided did not totally elimin: waning of the kingdon But in terms of basic presented in the tradi

16 Ben-Amos was told to Oba Eweka II, with th For a biography of Eghar Egharevba of Benin', $\mathrm{Hi}$

it See Bradbury, 'Chr

18 See note 3 above $f$ Egharevba that can be co support his date of 1700 Studies, 23 discussed dat on information given to years each king reigned. the rest of the chronol Problems', 27-37.

${ }_{20}$ Traditions about $t$ Southern Nigeria (Lond A Political Intelligence $F$ of Local Government, $1485-1700$, (Vienna, 19 Emblems of identity in 
enteenth century, David ton $(17 \text { I } 6-38)^{11}$

in, they were limited in officials were generally s, who were encouraged ed. ${ }^{12}$ While this limited on, it did not limit their they had a vital interest that trade was by all east one Dutch factor is well have provided him m.

ich must be resolved in out political history that 11 circle consisting of the 1 ancestors), and various a be expected to present Short History of Benin is nin history as preserved tern sort that uses oral eginning in the r93os, te oral traditions from om had been alive prior lection, Egharevba then al audience: on the one style history to British

Is Dierick Ruiters by Klaas en naar West Afrika, (The are to be found in Archivio e series Scritture Originali - A partial list is in Ryder, 1 dated later than 1657 . In Salvadorini), Le missione a zventura da Firenze (Milan, I's letter of Sept. I, I I Ox. $\mathrm{KG}$ for the most part. Set

van het Gout-Koninkirjk van agination of the original $\mathrm{Mb}$ sh translation of Albert van ast of Africa (Oxford, rg8g). 2 and the Europeans, passim nde' a name given to titlod I36, cited in Ryder, Bexty title (egie) in the politict gbere). From the nineteents enin have been the Uriming fs) and the Eghaevbo $n^{\prime} a^{4}$ ge in Benin today, whethy ed here along with the test

colonial officials and western intellectuals, and on the other, to satisfy the expectations of the Edo royalty and elite. ${ }^{16}$

With this audience in mind, Egharevba took what were a series of king lists held in memory by Edo genealogical specialists, ${ }^{17}$ together with widely circulated legends about their reigns, and made them into a dynastic chronology. He worked out dates, sorted out discrepancies and generally created order. His dating method was never fully explained, but it is remarkable that his proposed dates for the kings since about 1735 are supported by written sources, many of which were unknown to him or anyone else at the time. ${ }^{18}$

In presenting the material, Egharevba bowdlerized some of the traditions, omitting, for example, the numerous royal adulteries that might have offended British sensibilities. And, most important for our purposes, he minimized episodes remembered in the oral tradition that might have been unpleasant for the royal family. Such expurgation is most clear in his treatment of the instability of the kingship in the seventeenth century, a crucial issue in understanding the roots of the civil war. Traditional versions concur that upon the death of Oba Ohuan (in 164I in Egharevba's chronology), there were no sons or brothers to inherit the throne. According to Egharevba, the result was that 'the throne was opened to rotation among different branches of the Royal Family'. ${ }^{19}$ This is a mild version of the traditions relating to these monarchs and does not explain exactly who participated in this rotation and what the consequences were. As we shall see, successions in the mid to late seventeenth century were marked with struggles between rival claimants to the throne, many of whom were not directly in the royal line of descent and were thus not totally legitimate (or, as the Edo say, were not 'divinely ordained', eire na ya we). ${ }^{20}$

Egharevba provided a fairly static picture of Benin political structure. $\mathrm{He}$ did not totally eliminate change: he was careful to portray the waxing and waning of the kingdom's fortunes and listed all the innovations of each $\mathrm{Oba}$. But in terms of basic political institutions, Egharevba accepted the view presented in the traditions he collected that the major political institutions

${ }^{16}$ Ben-Amos was told in 1976 that Egharevba had to read the manuscript of his book to Oba Eweka II, with the Edaiken (heir apparent), who was to be Akenzua II, sitting in. For a biography of Egharevba, see U. Usuanlele and T. Falola, 'The scholarship of Jacob Egharevba of Benin', History in Africa, 21 , 1994.

17 See Bradbury, 'Chronological Problems'.

18 See note 3 above for the death of an $O b a$ in 1735 for the earliest date given by Egharevba that can be confirmed by documents. Note, however, that documents do not support his date of 1700 for the accession of the king who died in 1735 . Bradbury, Benin Studies, 23 discussed dating with Egharevba, who told him that his time scale was based on information given to him by the Esekhurhe, a royal genealogist, as to the number of years each king reigned. Perhaps the information on Ewuakpe is erroneous, thus throwing the rest of the chronology off. For more discussion, see Bradbury, "Chronological Problems', 27-37. 19 Egharevba, Short History, 34.

${ }^{20}$ Traditions about this period can be found in P. Amory Talbot, The Peoples of Southern Nigeria (London, ist ed. I 926, reprinted 1969), I, 160-70; J. Macrae Simpson, A Political Intelligence Report on the Benin Division of the Benin Province, 1936 (Ministry of Local Government, Benin City); and Mechthildis Jungwirth, Benin in den Fahren I485-I700, (Vienna, I968), and Paula Ben-Amos, 'Who is the man in the bowler hat? Emblems of identity in Benin royal art', Baessler-Archiv $3 \mathrm{I}$ (1983), $\mathrm{I}_{\mathrm{I}} \mathrm{I}-8_{3}$. 
were established by Obas Ewuare, Ozolua and Esigie, who probably reigned in the late fifteenth and sixteenth centuries and always functioned as they appear to have done at the time of the colonial conquest. These Obas are very popular in contemporary storytelling and they act as narrative magnets in attracting interesting events. Moreover, since 'antiquity' is an important constitutional principle, attributing ancient origins to institutions establishes and heightens their legitimacy. As Bradbury points out, the Edo tend to attribute the introduction of most political institutions and much economic, craft and ritual specialization to these kings. "There are more traditions and legends concerning these Obas than any other; indeed their fame is such that there is a tendency to attribute events to their reigns whenever there is doubt about them' ${ }^{21}$ Clearly, if we want to determine if institutional change has taken place, we need to examine the civil war period with the contemporary documents at hand, and a skeptical eye on Egharevba's tradition-based assessment.

\section{BENIN IN THE SEVENTEENTH CENTURY}

Benin as it appears in documents of the seventeenth century was a wealthy and centralized kingdom. The natural reflection of centralized wealth was its magnificent capital city, one whose archaeology has only begun to be explored. ${ }^{22}$ Early European visitors never failed to be impressed with the city. The Portuguese compared it with Lisbon, the Dutch with Amsterdam or Antwerp, the Italians with Florence, and the Spaniards with Madrid ${ }^{23}$ Its size was matched by dense habitation; houses built close to each other along long, straight streets. The royal palace, a city within the city, was also impressive, with countless squares and patios and innumerable doors and passageways, all richly decorated with the art that has made Benin famous. ${ }^{24}$

21 Bradbury, Benin Studies, 33.

${ }^{22}$ Graham Connah, The Archaeology of Benin (Oxford, 1975).

23 APF: SOCG, vol. 517 , fol. 308v, Lourenço Pinto to Propaganda Fide, 28 May 1693 (Lisbon); for comparisons to Amsterdam, see the report of the first visit by Dutch to Benin, I 598 cited in Ray A. Kea, 'Firearms on the Gold and Slave Coasts from the sixteenth to the nineteenth century', Fournal of African History, 12 (1971), 187; Dapper, Beschrijvinge, 122; for Florence, see Bonaventura da Firenze, 'Come entrò la fede di Giesu Christo nel regno d'Ouere per la Prima Uolta,' fol. $28 \mathrm{v}$, in Salvadorini (ed.), Missioni (with original foliation of MS marked); for comparisons to Madrid, see APF: SOCG, vol. 249, fol. $35 \mathrm{rv}$, Felipe de Hijar to Propaganda Fide, 25 July 1654; de Sandoval, Instauranda, $7^{8-9}$.

${ }^{24}$ Dapper, Beschrijvinge, 122; de Marees, Beschryvinge, I I5a. See especially the reports of the Capuchins who visited the palace: APF : SOCG, vol. 249 , fol. $328 \mathrm{v}$ and 351 (next folio of letter); and Biblioteca Nacional de Madrid, Antonio de Teruel, Descripcion narrativa de la mission serafrica de los Padres Capuchinos en el reyno del Congo', ( $c$. 1664). This last manuscript contains a long account clearly written by or based on that of Angel de Valencia, a friend and companion of Teruel (but the hand is Teruel's throughout). It was subsequently used by Mateo de Anguiano in his chronicle (Biblioteca Nacional de Madrid Ms 18 178, 'Segunda Parte de la Chronica ...' 1705) and eventually published by Buenaventura de Carrocera, Misiones Capuchinos in Africa, II (Madrid, 1957). Other elements of de Valencia's material are found in the Arquivo Provincial de los Capuchinos de Valenca, Jose de Alicante, 'Cronica de los Capuchinos de Valencia desde 1650 hasta 1722 '. Cavazzi's better know account in Istorica Descrizione de tre' regni Congo, Matamba ed Angola (Bologna, I687), Libro V, contains no new material. An explicit reference to the art can be found in APF: SOCG vol. 517 , fol. $308 \mathrm{v}$, Letter of Lourenço Pinto, 28 May I693. he city was orderly, $w$ houses appeared pol The orderliness of thi oreaucratic rule. We r pointed officials, ofte: periors, formed a hie: arge areas of social, po: it the supervision as Isited the city about it wim from seeing too $\mathrm{m}$ Capuchins were not to ! would teach them a so] Control was not limi noted that the governm on the Ughoton-Benin drop of water was pa suggested that the elab for several miles in eac well be more for conts which are not in use to ways', thus preventing city. ${ }^{29}$ This interpret scription of Benin's hi pierced by gates man who come by. ${ }^{30}$

Such a system of order, perhaps includ although European d victims in sacrifices, with the exception of outside European vie massive surplus-ext century Benin had especially males, to fairly large numbers

The pinnacle of $\mathbf{E}$ surprise that once $t$

25 Dapper, Beschrijo Fide, 28 May 1693.

${ }^{27}$ APF : SOCG, vol. Acontesidas en la Mis: marked in Salvadorini

${ }^{28}$ Dapper, Beschrije

29 P. J. Darling, "No of Archaeology 6 (I976 30 de Sandoval, Inst translation of the Spa

${ }^{31}$ de Marees, Besch

s2 Ryder, Benin an

38 Bradbury, Benin this case by older doc 
who probably reigned ays functioned as they st. These Obas are very as narrative magnets in quity' is an important institutions establishes $s$ out, the Edo tend to as and much economic, are more traditions and 1 their fame is such that whenever there is doubt nstitutional change has with the contemporary evba's tradition-based

\section{TURY}

century was a wealthy ntralized wealth was its as only begun to be be impressed with the Jutch with Amsterdam ards with Madrid. ${ }^{23}$ Its ose to each other along hin the city, was also nnumerable doors and made Benin famous. ${ }^{24}$

75).

aganda Fide, 28 May 1693 he first visit by Dutch to ad Slave Coasts from the $y, 12$ (197x), 187; Dapper, ;, Come entrò la fede di $28 \mathrm{v}$, in Salvadorini (ed.), sons to Madrid, see APF : Fide, 25 July 1654 ; de

I $5 a$. See especially the vol. 249 , fol. $328 v$ and 351 iio de Teruel, Descripcion i el reyno del Congo', ( $\boldsymbol{c}$. ten by or based on that of ut the hand is Teruel's $\mathrm{n}$ his chronicle (Biblioteca ...' 1705 ) and eventually os in Africa, II (Madrid; he Arquivo Provincial de Capuchinos de Valencin sa Descrizione de tre' regm ins no new material. An 517 , fol. $308 v$, Letter of
The city was orderly, well laid out, and sparkling clean so that the walls of the houses appeared polished. ${ }^{25}$

The orderliness of the town was perhaps a reflection of a highly restrictive bureaucratic rule. We use the term bureaucratic here to mean that stateappointed officials, often serving on limited terms and responsible to their superiors, formed a hierarchy that led to the king, which sought to control large areas of social, political and economic life. European visitors certainly felt the supervision as well - Derick Ruiters was given a 'guard' when he visited the city about 1600 , whose real function, he believed, was to prevent him from seeing too much. ${ }^{26}$ When a palace official decided in 1652 that the Capuchins were not to be taught Edo, they could not find a single person who would teach them a solitary word. ${ }^{27}$

Control was not limited to supervision of foreigners' movements, Dapper noted that the government had thoughtfully placed a large water jar mid-way on the Ughoton-Benin road, complete with a guard who insured that each drop of water was paid for by the thirsty travelers. ${ }^{28} \mathrm{P}$. J. Darling has suggested that the elaborate system of earthworks that surrounds Benin City for several miles in each direction and extends out into the rural areas might well be more for control of movement than for defense. These earthworks, which are not in use today and have no modern analogy in Benin, 'face both ways', thus preventing movement out of, or across, Benin as well as into the city. ${ }^{21}$ This interpretation is strengthened by Alonso de Sandoval's description of Benin's high walls, topped with thick vegetation and occasionally pierced by gates manned by armed sentries who demanded passes from all who come by. ${ }^{30}$

Such a system of tight supervision also implied a controlled economic order, perhaps including forced labor. Slaves certainly abounded in Benin, although European descriptions generally saw them as personal servants or victims in sacrifices, and not as rural workers. ${ }^{31}$ Of all the features of Benin, with the exception of artisinal activities, its productive activities lay generally outside European view. However, some features of Benin do suggest that a massive surplus-extracting apparatus was in place. Since the sixteenth century Benin had been very reluctant to give up any of its workforce, especially males, to Europeans as slaves. ${ }^{32}$ Wealthy people owned slaves in fairly large numbers, perhaps used them on farms. ${ }^{38}$

The pinnacle of Benin's system of control rested with the Oba. It is no surprise that once they grasped the structure of Benin, Capuchin priests

${ }_{25}$ Dapper, Beschrijuinge, 122; APF: SOCG, vol. 517, fol. $308 \mathrm{v}$, Pinto to Propaganda Fide, 28 May 1693 . $\quad{ }^{26}$ de Marees, Beschryvinge, I $5 \mathrm{~b}$.

${ }^{27}$ APF : SOCG, vol. 249, fols. 332-9, [Alonso de Tolosa], 'Breve Successo de las Cosas Acontesidas en la Mission del Benin", 20 Nov. 1652 , published with original foliation marked in Salvadorini, Missioni Appendix 4, and in Brásio, Monumenta 15, 634-39.

${ }^{28}$ Dapper, Beschrijuinge, 122.

${ }^{29}$ P. J. Darling, 'Notes on the earthworks of the Benin empire', West African Fournal of Archaeology 6 (1976), 143-9.

${ }^{30}$ de Sandoval, Instauranda, 78 . The authors wish to thank Serena Van Buskirk for her translation of the Spanish text.

${ }^{31}$ de Marees, Beschrjuinge, 1 16b; Dapper, Beschrijuinge, 122-31 passim.

32 Ryder, Benin and the Europeans, passim.

33 Bradbury, Benin Studies, 53, based it seems on oral recollections, but confirmed in this case by older documents. See de Marees, Beschrivinge, I $15 \mathrm{~b}$. 
worked hard to convert the king to Christianity, for as Francesco da Monteleone noted in $169 \mathrm{x}$, though probably reflecting attitudes of the precivil war period, if they could win over the $O b a$, then 'all, all would be converted ' ${ }^{34}$ The $O b a$ was one of the few hereditary offices in the political structure, and maintaining the succession within one family (in contrast, for example, to the Yoruba where families rotate) allowed a single small group to control the whole vast system.

The Oba's control had substantial ideological justification. From the earliest period of contact, Portuguese navigators noted the reverence with which monarchs were treated, the special patterns of deference directed towards them and the awe and respect in which they were held by the populace, who regarded them as divine. ${ }^{35}$ This reverential attitude was observable well into the seventeenth century. ${ }^{36}$

The power of the Oba was based ideologically on his divinity, but concretely on his control over a military machine. Dapper points out that:

[t] ]he King of Benin can in a single day make 20,000 men ready for war, and, if need be, 180,000 , and because of this he has great influence among all the surrounding peoples ... . His authority stretches over many cities, towns, and villages. There is no King thereabouts who is in the possession of so many beautiful cities and towns, or is his equal.

In the same discussion, Dapper notes that the $O b a$ 'rules with absolute and harsh power, and regards all his subjects, no matter what great nobles they may be, as slaves' ${ }^{37}$

A major source of his power over the chiefly bureaucracy was his control over the granting of official titles. This enabled him to manipulate the chiefly system by promoting those loyal to him and withholding promotion from those he opposed. From the early sixteenth century, documents reveal a political structure in which a service aristocracy of officials played an important role in governing the kingdom, but they do not always reveal enough to verify for us what the relationships between the king and the various groups of titleholders were. In 1505 King Manuel of Portugal gave

34 APF: SRC, Congo, vol. 2, fol. 479, Francesco da Monteleone to Propaganda Fide, 25 Apr. $169 \mathrm{r}$.

${ }_{35}$ 'Navigazione da Lisbona all'isola di San Tomé, posta sotta la linea dell'equinoziale, scritta per un pilotto portoghese e mandata al magnifico conte Rimondo della Torre ... tradotta di lingua portoghese in italiana', in Giovanni Battista Ramusio Delle navigationi et viaggi raccolte da $M$. Gio. Battista Ramusio (Venice, 1550, revised ed. [this material unchanged] 3 vols., Venice, 1606 ; modern reset edition with new pagination, ed. M. Milanesi, 6 vols., Milan, 1978) I: 571-2; Thomas Windam, 'The voyage of M. Thomas Windam to Guinea and the kingdom of Benin', in Richard Eden, The Decades of the New Worlde (London, I555), reprinted in Richard Hakylut, Principal Navigations and Navigations of the English Nation (London, ${ }_{5} 89$ ) II, ii, 12, mod. ed. Glasgow, 1906, VI: $148-9$ [the modern edition marks original volume, chapter and folio numbers].

${ }^{36}$ Colombino de Nantes to Propaganda Fide, 26 Dec. I640 (but reflecting travels of 1636), Brásio, Monumenta 8: 464-5; de Sandoval, Instauranda, 81 .

37 Dapper, Beschrijvinge, I 28 ; also see 'Aenwÿsinghe', fol. 14 [Jones' edition and English translation mark the original foliation, West Africa in the Mid-Seventeenth Century]; Andreas Josua Ulsheimer, 'Warhaffte Beschreibung ettlicher Reisen in Europa, Africa, Asien und America' [MS of 1616 ] (mod. ed. and English trans. Adam Jones) in German Sources for West African History, $1599-1669$ (Wiesbaden, 1983), fol. 55 a [original foliation marked in edition and translation]. gifts to three officials be 'veador' (overseer in Po Later sixteenth century s in the sources) and the $U$ called in $1526 .{ }^{40}$ The 'Os in $1516,{ }^{41}$ while the yout 'captains' as guardians ar these sources do not government that migh documents.

The references to Ber English travelers and th are much less helpful: $F$ with 'officials' and 'nobl negotiations, but witho these titles. ${ }^{43}$ Andreas $\mathrm{U}$ surrounded by 'military impression that the ru offend the king, even if [Öberster]', he would or a visitor in the following of soldiers, but gave no each other. ${ }^{45}$

The first explicit de from Alonso de Sando captains between 1618

The kingdom is gov correspond to our cha their clothes; some at green; and the captai lawsuits, debates and

By far the most $d$ compiled about $1640 \mathrm{~b}$

38 Arquivo Nacional d Maço 166 , fols. $23,24,35$ in the early sixteenth cen

${ }^{39}$ The Portuguese tern franca, as later writers re sources, joining a large $r$ from Portuguese such as 40 AN'TT Corpo Cron João', fol. 9 .

41 'Imquiriçam que se Ilha de Santomé, que fo Missionaria Africana, ser el Rey de Benj'; 497, kir heading, but internal dat

${ }_{42}$ João Fialho to Antó

43 In Richard Hakluy 1589).

44 U1

45 De Marees, Beschr 
for as Francesco da $g$ attitudes of the prehen "all, all would be offices in the political family (in contrast, for d a single small group

astification. From the ed the reverence with of deference directed ney were held by the verential attitude was

on his divinity, but apper points out that:

on ready for war, and, if nfluence among all the many cities, towns, and possession of so many

Ales with absolute and what great nobles they

dcracy was his control manipulate the chiefly ding promotion from , documents reveal a of officials played an do not always reveal een the king and the nuel of Portugal gave

eone to Propaganda Fide,

la linea dell'equinoziale, conte Rimondo della i Battista Ramusio Delle ce, I 550, revised ed. [this with new pagination, ed. am, "The voyage of $M$. chard Eden, The Decades ut, Principal Navigations mod. ed. Glasgow, r9o6, and folio numbers].

(but reflecting travels of 81 .

I4 [Jones' edition and in the Mid-Seventeenth tlicher Reisen in Europa, sh trans. Adam Jones) in , 1983 ), fol. 55 a [original gifts to three officials besides the king of Benin, the 'chief chancellor', a "veador" (overseer in Portuguese) and the ruler of the port of Ughoton. ${ }^{38}$ Later sixteenth century sources name these 'veadors' : 39 the Osodin ('Osody' in the sources) and the Uwangue ('Ohũ agua'), who received gifts when ships called in $1526 .{ }^{40}$ The 'Osody' was even noted as ruling in the king's absence in $1516,{ }^{41}$ while the youthful king who was ruling in 1516 had two unnamed 'captains' as guardians and was wholly 'under their power'. ${ }^{2}$ Unfortunately, these sources do not provide a comprehensive description of Benin's government that might allow us to confirm elements found in later documents.

The references to Benin found in later sixteenth-century documents by English travelers and the accounts left by early German and Dutch visitors are much less helpful: Richard of Arundell, visiting in 1589 , noted meeting with 'officials' and 'noblemen' as well as with a 'Veedor' who did substantial negotiations, but without giving much hint about the organization behind these titles. ${ }^{43}$ Andreas Ulsheimer, a visitor of 1601 , referred to the king being surrounded by 'military commanders' (Kriegsobristen). Ulsheimer gives the impression that the ruler was supreme for he noted that should anyone offend the king, even if it were 'his closest counselor [Raht] or commander [Öberster]', he would order that person's head be cut off. ${ }^{44}$ Dierick Ruiters, a visitor in the following year, noted that there were nobles and commanders of soldiers, but gave no indication of their relationship to either the ruler or each other. ${ }^{45}$

The first explicit description of Benin's governmental structure comes from Alonso de Sandoval, who obtained it probably from Portuguese sea captains between 1618 and 1624 . He writes:

The kingdom is governed by associations [juntas] of prudent men, who correspond to our chancelleries, and each one has their insignia in the color of their clothes; some are dressed in white, others in yellow, others in blue or green; and the captains of these associations are regular judges who resolve lawsuits, debates and conflicts. ${ }^{46}$

By far the most detailed description of Benin government was that compiled about $\mathrm{r} 640$ by Samuel Bloomert, a West India company director,

${ }^{3}$ Arquivo Nacional de Torre do Tombo (henceforward ANTT), Nucleo Antigo, Maço 166 , fols. 23, 24, 35v, 37, 63v, 317v, 326v, lists of presents for the King of Benin in the early sixteenth century.

39 The Portuguese term was clearly borrowed into the local Portuguese based lingua franca, as later writers render them into their own language, such as 'fiador' in Dutch sources, joining a large number of terms for African institutions ultimately borrowed from Portuguese such as 'caboceiro' or 'fetiçeiro' in other areas.

40 ANTT Corpo Cronologico, part II, maço I 51 , documento 69, Ship's book, 'São João', fol. 9 .

41 'Imquiriçam que se tyrou nesta Ilha de SantÃtonjo sobre a nao dos armadores da Ilha de Santomé, que foy a Benj', I9 Nov. 1516, António Brásio (ed.), Monumenta Missionaria Africana, series I (1 5 vols., Lisbon, 1952-88) I, 494: "o soo dito Regidor porr el Rey de Benj'; 497, king was away at a war (editor has misdated document to 1526 in heading, but internal dates are all $15 I 6$ ).

${ }^{42}$ João Fialho to António Carneiro, 24 Aug. 1514 , in Brásio (ed.), Monumenta I: 413.

43 In Richard Hakluyt, The Principal Navigations of the English Nation (London, 1589). A4 Ulsheimer, 'Wafhafte Beschreibung', fols. 54a, 55a.

45 De Marees, Beschrijoinge, 116b, $117 \mathrm{~b}$. ${ }^{4}$ de Sandoval, Instauranda, 80. 
who was the main source that Olfert Dapper used for his I 668 description of Africa. ${ }^{47}$ According to Dapper, the king had "ruled the kingdom, with, among others, three Overseers, which the Portuguese called "Fiador" [veador]'. Elsewhere, Dapper gave their titles 'Ongogue, Ossade and Arribo' - two of which names could easily be matched with the 'Osodi' and 'Ohu Agwe', powerful great men of the sixteenth-century Portuguese accounts; moreover, Dapper continued, they 'had no one over them but the Fieldmarshal [Owe Asseri or Siaserre] ${ }^{48}$ (who is next to the king) and the king's mother' ${ }^{49}$

It seems likely that these powerful great men were among the 'captains' of the associations that de Sandoval mentioned. Moreover, accounts of visiting Capuchin missionaries written within a decade of Dapper's information note considerable royal power over all the 'nobility' (fidalgos): according to a 'Description of Benin' written about 1652 , offices given by the king were not hereditary, 'even if they are the sons of great men (grandes)' as the king gave these to 'each one in particular'.50 These accounts thus describe a royal power that controlled a substantial hierarchy organized by associations under great men but answering to the Oba.

\section{THE TURNING POINT}

Although these documentary accounts suggest an administration firmly under royal control, oral traditions and, to some extent, documentary accounts suggest that at some point in the early seventeenth century Obas began to lose power vis-à-vis the associations. There are three factors that appear to have been causes of the weakened monarchy: a crisis in the royal succession, growth in the power of the officials, and changes in trade and commerce, all of which led to a stronger role for the bureaucratic associations.

\section{Royal succession}

Royal traditions have little to say of the six or seven Obas who ruled Benin between the reign of the last great warrior king, Ehengbuda - that is, from the beginning of the seventeenth century - up until the time of $O b a$ Ewuakpe, provisionally dated to the late seventeenth century, although they do not by themselves point to any sort of social change. As Ben-Amos has pointed out elsewhere, ${ }^{51}$ the brief accounts recorded by Egharevba ${ }^{52}$ are very

47 Dapper, Naukeurige Beschijuinge, 128. The passage probably refers to the 1640 , since the date of 1644 is mentioned in a description of nearby Warri, 133 . It is not found in the same way or detail in the two other Dutch texts that appear to have used the same sources, Leers in 1665 and the Universitetsbibliotek Leiden MS 927, 'Aenwijsinge' (ed. Jones) of the early $1650 \mathrm{os}$, fols. 14-14 $\mathrm{v}$ contain a passage about the king.

4. These terms are not used in this particular passage, but rather later on p. 130 to describe the ritual followed upon the death of the king, and is mentioned incidentally by this title on p. 127. The names 'Ongogue', 'Ossode', 'Arribo', and 'Siaserri' refer to the Uwangue, Osodin, Eribo and Iyase (also called Iyasere).

$4 \theta$ Dapper, Beschrijvinge, 128.

50 APF : SOCG, 249, fol. 3I Iv, Anon. [probably Felipe de Hijar], 'Descripcion del Reyno de Benin', n.d., published in Salvadorini, Missioni, with original foliation marked, also in Brásio, Monumenta, 15.

51 The following section about the seventeenth-century kings is taken from Ben-Amos, 'Royal art and ideology in eighteenth-century Benin', Iowa Studies in African Art I (1984), 67-86. curious. Most of the se short reigns. The reig Ahenkpaye, was actua having gambled away t in light of the reverenc

Stories about two o king's only child, Ohu her father, Oba Ehengt to the kingship. ${ }^{53}$ The waters, Olokun, and g: of these accounts kingl ineligible to become $r$ in the second because in themselves divine. serious difficulties wit

More important, it flung members of the have not been recordec Royal genealogies (of before the seventeenth death of $\mathrm{Oba}$ Ohuan ( or brother to take ov precise names and or Akengbayi, Akenzam clue to the dissensio version tend to minim is what happened to

Several independer throne in the sevente the founder of the $B$ who is said to have c and fathered Eweka District Officer Mac traditions, after $\mathrm{Oba}$ recorded a different the coronation, that

In 198I, Ben-Amo the royal ancestors, $t$ long reigns because

53 This is another ex being 'girlish'. ${ }^{54} \mathrm{Egl}$ 55 Bradbury, Benin S

57 Talbot, Peoples, It Ihama of Thogbe, pers.

38 Jungwirth, Benin i there was the fear that $t$ child to succeed him. witnessed at the time o line of royal succession of Ohuan'. 
is $\mathrm{I} 668$ description of the kingdom, with, ese called "Fiador" ngogue, Ossade and with the 'Osodi' and -century Portuguese ne over them but the to the king) and the

long the 'captains' of accounts of visiting er's information note lgos): according to a by the king were not des)' as the king gave hus describe a royal by associations under

dministration firmly xtent, documentary teenth century Obas re three factors that a crisis in the royal hanges in trade and aucratic associations.

bas who ruled Benin buda - that is, from 1 the time of $O b a$ thury, although they . As Ben-Amos has gharevba ${ }^{52}$ are very

ly refers to the 1640 , rri, I 33. It is not found $r$ to have used the same 927, 'Aenwijsinge' (ed. le king.

ther later on p. I 30 to ntioned incidentally by $d$ 'Siaserri' refer to the

'ijar], 'Descripcion del ginal foliation marked, taken from Ben-Amos, udies in African Art I $-9$. curious. Most of the seventeenth century rulers appear to have extremely short reigns. The reigns of several are marked with rebellions and one, Ahenkpaye, was actually deposed. Another, Ahenzae, is remembered for having gambled away the royal coral beads, a particularly horrifying image in light of the reverence with which the Edo regard these beads.

Stories about two of the kings are particularly interesting. In one, the king's only child, Ohuan, was born a female and only through the magic of her father, Oba Ehengbuda, was she transformed into a male, a suitable heir to the kingship. ${ }^{53}$ The other, Akengboi was possessed by the god of the great waters, Olokun, and grew the special priestly dreadlocks (ihiagha). In both of these accounts kingly norms are violated: in the first because females are ineligible to become rulers (thus necessitating the magical transformation), in the second because rulers should not be possessed by any deity as they are in themselves divine. At a symbolic level these two stories are indicative of serious difficulties within the kingship.

More important, it appears that the royal line was dissipated so that farflung members of the royal family, whose exact genealogical relationships have not been recorded, struggled for the kingship and weakened it seriously. Royal genealogies (of which four versions have been published) propose that before the seventeenth century succession was from father to son, but at the death of $O b a$ Ohuan (dated by Egharevba to around I64I) there was no son or brother to take over the throne. ${ }^{54}$ After that they do not agree on the precise names and order of rulers. ${ }^{55}$ Talbot's account that Obas Ehenzai, Akengbayi, Akenzama or Akenzayi had all been selected 'under protest' is a clue to the dissension that Egharevba and other supporters of the royal version tend to minimize. ${ }^{56}$ The issue at the heart of the succession problem is what happened to the royal line of descent.

Several independently collected traditions suggest that the Obas on the throne in the seventeenth century were not in the core line of descent from the founder of the Benin royal dynasty, Aramiyan (Yoruba: Oranmiyan), who is said to have come from the kingdom of Ife, married an Edo woman and fathered Eweka I, the first $O b a{ }^{57}$ Indeed, it is quite likely that, as District Officer Macrae Simpson recorded from early twentieth century traditions, after Oba Ohuan died the line of Aramiyan 'died out'. Jungwirth recorded a different version in use among royalty in recent years, as sung at the coronation, that the royal line was 'about to die out' but was saved. ${ }^{58}$

In 198I, Ben-Amos was told by Chief Ihama of the Ihogbe, the priests of the royal ancestors, that the Obas between Ohuan and Ewaukpe did not have long reigns because 'they were not divinely ordained [eire na ya we]',

53 This is another example of Egharevba's bowdlerization: he cites Ohuan only as being 'girlish'. ${ }^{54}$ Egharevba, Short History, 34, and Bradbury, Benin Studies, 31.

55 Bradbury, Benin Studies, 20-I.

${ }^{57}$ Talbot, Peoples, I66-I67, Macrae Simpson, Political Intelligence Report (n. 25), 8, Ihama of Ihogbe, pers. comm. to Ben-Amos, 1981 .

58 Jungwirth, Benin in den fahren $1485^{-17} 700,204$ was told that: 'In the time of Ohuan there was the fear that the royal line was going to be extinct because he did not have any child to succeed him. In commemoration of this Ekasa dancers still sing today as I witnessed at the time of Eweka II : Aiguobasimwim ... who took the title Eweka II the line of royal succession shall not be extinct in your hand as it was about to be in the time of Ohuan'. 
probably because these Obas were chosen from very remote branches of the royal family that were not in the core line of divine inheritance. In accordance with general Edo belief in reincarnations within a lineage, Obas are considered reincarnations of previous monarchs; as a result, anyone coming from remote branches of the family cannot be divinely ordained. While this explanation may be a contemporary view of past events, it does point to a crisis of legitimacy in the seventeenth century.

Documents from the sixteenth and seventeenth centuries support the idea that succession in a single line stopped in the seventeenth century. Early texts confirm father-to-son succession, documented in the ${ }_{5} 517$ succession $^{59}$ and by Ulsheimer, visiting in $160 \mathrm{r}$, who noted that the king's eldest son (eltister Sohn) succeeded him. ${ }^{60}$ But matters changed in Dapper's account of the 1640 . 'The crown passes on to the son, and if there is no son, then to the brother', he wrote, but added another custom which suggests that while father-to-son succession was still regarded as the norm, it was no longer followed in his day. ${ }^{61}$ In Dapper's account of the succession, dying Obas revealed their wishes about their successor to the Onegzwa, a titled official, ${ }^{62}$ who then announced it, suggesting that the proclamation of succession had shifted to the administration. Administrative control may well have arisen from succession disputes, Dapper elsewhere indicates that the first act of any $O b a$ was to eliminate his brothers, although he noted that recently some had been permitted to live, perhaps with eventual disastrous consequences. ${ }^{63}$

\section{Bureaucratic developments}

As rivalries between brothers at succession may have weakened the Obas, there is also evidence that the bureaucratic associations that supervised daily life so closely in Benin increased in strength and independence, even to the point of usurping the $O b a$ 's power in more than just succession. Several pieces of evidence lead to this conclusion. Early seventeenth-century witnesses noted that the $O b a$ was now restricted to the palace, only coming out occasionally (once a year according to Ulsheimer in 1601 and twice according to Ruiters in 1602 ), a practice that would continue throughout the century. ${ }^{64}$ The withdrawal of the king from public activities seems to have occurred concurrently with changes in the relative power of the palace administration.

Royal traditions state that at the end of his reign, Oba Ehengbuda, last of the great warrior kings, passed a law that the Uwangue, one of the three leading administrative posts, could not be killed, thereby removing one of the great sources of the Oba's power - his right to take the life of his subjects. Such a decree suggests that the titleholders were gaining political strength

58 Missionary letter, 24 Aug. 1517 , in Brásio, Momumenta 1,413 , the reason for believing this was father-to-son succession is the fact that the king was so young that the Osodin had to serve as a guardian, while collateral succession would probably have allowed a more experienced man to take over. Ulsheimer, 'Warhaffte Beschreibung', fol. 57a.

61 Dapper, Beschrijvinge, 128 .

62 Ryder, Benin and the Europeans, 16 assumed the title was a poorly transcribed variant of the Uwangue, but elsewhere Dapper clearly writes Ongogue as one of the great fiadors, and uses Onegwa several times in the latter passage; see Dapper, Beschrijoinge, 128 and 130.

63 Dapper, Beschrijuinge, 133.

(4) Ulsheimer, 'Warhaffte Beschreibung', fol. 53 b; de Marees, Beschryvinge, I I $7 \mathrm{a}$. relative to the monar his. A second law, saic Oba from leading mili another high adminisi captain existed, altho Ulsheimer, who serv campaign against $L$ : Egharevba's tradition $O b a$ who succeeded considerable power, affairs of state.

This situation co Capuchin priests w] impression that offic they thought he mig veadores prevented th whether or not this v a permanent break

This usurpation o without its challeng tried to reassert roya to pay coronation fe action appears to ha which had him det 'Kambadje' (a very expeditions, probab assertiveness on his collection that Dapp killed and then seize exiled to the island be used to point to according to Dapp overthrown, sugges over succession was 1650 s and describe successors of 'Kan long-range consequ

An important fe century appears to

de Marees, Bes $32 a-32 b$, the campaig describing royal camp

Bg Egharevba, Shor

B7 Ryder, Benin an evidence for a sort of

63 Dapper, Nauket 1645 was named ' $\mathrm{Ga}$ thinks that Kambadj 70 'Aenwÿsinghe',

7 Dapper, Nauken 
remote branches of the divine inheritance. In within a lineage, Obas s; as a result, anyone be divinely ordained. of past events, it does tury.

turies support the idea ateenth century. Early the I 5 I 7 succession ${ }^{58}$ the king's eldest son in Dapper's account of is no son, then to the h suggests that while orm, it was no longer uccession, dying Obas egwa, a titled official, ${ }^{62}$ tion of succession had may well have arisen that the first act of any that recently some had ous consequences. ${ }^{63}$

e weakened the Obas, $s$ that supervised daily pendence, even to the st succession. Several seventeenth-century e palace, only coming er in 1601 and twice atinue throughout the tivities seems to have power of the palace

ba Ehengbuda, last of gue, one of the three eby removing one of he life of his subjects. ing political strength

3, the reason for believing o young that the Osodin ably have allowed a more chreibung', fol. 57a.

oorly transcribed variant ; one of the great fiadors, r, Beschrijuinge, 128 and : Beschryoinge, r ז relative to the monarch and were beginning to separate their powers from his. A second law, said to have been promulgated by Ehengbuda, forbade the $O b a$ from leading military expeditions, this task being entrusted to the Iyase, another high administrative official. Ruiters, in 1602 , specifies that a military captain existed, although he does not give any details on his independence. Ulsheimer, who served with a Benin army at about the same time in a campaign against Lagos, saw the armies commanded by a 'general'.65 Egharevba's traditions state that the Iyase in fact rebelled against Ohuan, the Oba who succeeded Ehengbuda. ${ }^{66}$ The separate military command, with considerable power, strongly suggests the Oba's loss of control over some affairs of state.

This situation continued into the middle part of the century. The Capuchin priests who visited Benin in the 1650 s were also under the impression that officials blocked the $O b a$ 's independent judgment. While they thought he might want to become a Christian, they believed that the veadores prevented their message getting through, though one cannot be sure whether or not this was simply a means of putting them off without making a permanent break with the missionaries. ${ }^{67}$

This usurpation of the royal prerogatives by the administration was not without its challenges, however. Tradition maintains that $O b a$ Ahenkpaye tried to reassert royal control over the administration principally by refusing to pay coronation fees and re-centralizing other fees in his own hands. This action appears to have met with united resistance from the administration, which had him dethroned. ${ }^{68}$ Dapper refers to an $O b a$ whom he names 'Kambadje' (a very close resemblance to Ahenkpaye) as leading military expeditions, probably in the 1630 s and 408 - perhaps further evidence of assertiveness on his part. ${ }^{69}$ Moreover, according to documents from the collection that Dapper used, the king, possibly the same Oba, had the Osodin killed and then seized and redistributed his wives; other great men might be exiled to the island of Oebo. ${ }^{70}$ Clearly the traditions and the documents can be used to point to conflict, although in this case 'Kambadje' died in office according to Dapper and was succeeded by his son rather than being overthrown, suggesting that at least in this case the administrative control over succession was broken. ${ }^{71}$ That said, the $O b a$ the Capuchins met in the 1650 and described as a captive of administration was certainly one of the successors of 'Kambadje', so this assertiveness must have been without long-range consequence.

An important feature of Benin government in the later seventeenthcentury appears to have been the growth of the bureaucracy's reach and

\footnotetext{
65 de Marees, Beschrivinge, II $7 \mathrm{~b}$; Ulsheimer, 'Warrhaftige Beschreibung', fols. $32 a-32 b$, the campaign against Lagos, waged at the 'king's request' by a general; $55 a$, describing royal campaigns, but not specifying if the king commanded in person.

${ }^{66}$ Egharevba, Short History, 34.

67 Ryder, Benin and the Europeans, 92-105, makes a strong case using some of this evidence for a sort of bureaucratic coup. Egharevba, Short History, 35-6.

${ }^{69}$ Dapper, Naukeurige Beschrijuinge, 132. In 'Aenwÿsinghe', fol. I4, the ruler of about 1645 was named 'Gamba die', probably the same king, more securely dated. Bradbury thinks that Kambadje may refer to Ehengbuda. See Benin Studies, 30-2.

70 'Aenwÿsinghe', fol. 14v. Jones reads his title as Ossato in his edition of the Ms.

71 Dapper, Naukeurige Beschrijoinge, 129.
} 
authority, even beyond its earlier seventeenth-century controlling intrusiveness. David van Nyendael's description of the bureaucratic associations' organization at the end of the seventeenth-century is remarkable, and, if accurate, points to a significant change in the organization of Benin administration, either just before or as a result of the civil war. In his account, van Nyendael divided the government of the country into three 'orders': the first were 'three Persons, called here great Lords or Great men', the second one called 'Street Kings' (Are de Roe, probably from the Portuguese Rei da Rua), and a third group of 'merchants', 'intercessors' and 'elders'. ${ }^{72}$ Van Nyendael placed them in a single chain of command, so that members of the first order chose officials from the second order for their appointments. ${ }^{73}$ This tiered structure appears in the European documentation for the first time in van Nyendael's discussion. Sandoval, earlier, had noted that some associations existed, but gave no suggestion of any relative ordering. Now it appears, if van Nyandael is correct, that the senior administration had control of a substantial junior administration under it.

\section{CHANGES IN TRADE PATTERNS}

The gradual growth in administrative power to challenge the $O b a$ s and profit from the succession problems was paralleled by commercial changes that helped to shift wealth and power from the hands of the Obas to the administration, especially its lower ranks, as Ryder noted. First of all, members of the bureaucracy seem to have taken many commercial activities from the Obas, as they had military roles, and secondly, the production of Benin's exports shifted from commodities that the $O b a$ traditionally controlled, like slaves, ivory, gum, and pepper, to cloth which was widely produced and gave a large number of people potential access to wealth. ${ }^{74}$

The outlines of this commercial change are visible in European records. In 1553 , English merchants lead by Thomas $W y$ ndham were received in person by the $O b a$, who in turn traded with them in person, a practice common in the sixteenth century and confirmed by Portuguese reports as well. ${ }^{75}$ By 1590 onwards, the king's chief veadors were intervening in trade, although the $O b a$ still had the last word. ${ }^{76}$ By the seventeenth century, the locus of trade had shifted from the $O b a$ 's palace to riverside villages, and although Dutch officials certainly did visit the city, the daily business seems to have been handled by local officials and traders, operating in the name of the king, ${ }^{77}$ a practice also described at the end of the century by van Nyendael. ${ }^{78}$

More important than the administrative involvement in the trade was the shift in the type of commodity. Dutch records indicate that ivory and pepper - two products that were centrally controlled - were exported at the beginning of the seventeenth century. According to a general description of trade written in 1623 , Dutch pepper merchants participated in an extensive credit system, including use of written notes, with the two royal officials in

\footnotetext{
${ }^{72}$ Bosman, Beschryvinge, 224-6. $\quad{ }^{73}$ Bosman, Beschriyvinge, 225-6.

${ }^{74}$ For further documentation of this shift and a thesis that it was related to royal decline, see Ryder, Benin and the Europeans, 88-9.

${ }^{75}$ Hakluyt, Principal Navigations II, ii, 12, mod. ed., VI, 149. On the Portuguese period, Ryder, Benin and the Europeans, 53-65. ${ }^{76}$ Hakluyt, Navigations (mod. ed.) VI, 459.

${ }_{77}$ Dapper, Beschrijvinge, $125-6$.

${ }^{78}$ Bosman, Beschryinge, 227.
}

charge of trade. ${ }^{79}$ Vol ships involved in the $\mathrm{E}$ ivory and 1,337 pounc According to Ryder were no longer being $\mathrm{s}$ ? Mid-seventeenth cen disappeared as an exp trade was not a mo widespread and in loc throughout the Benin I 588 , followed by $U$ through Lagos, then i visiting Benin about which are exported $f$

Weaving was essen time, if more recent $d$ personal use, as the $x$ other African people, middle of the sevente or on European shipt European shipping $\mathrm{c}$ the interior of centra

Organization of $t$ trading associations routes that linked $t$ seem to have been th description, along w in Ughoton, "the kin (koopman) who alor officials seem to hav he noted that when dispatch 'two or thr whites to trade'. ${ }^{89} 7$

79 Nicholaas van Wa in Europa ... (Amster

80 Van Wassenaer,

s1 Ryder, Benin and India Company' recor very difficult, so this i

82 'Aenwÿsinghe',

83 Welsh's account "Warhaftte Beschreib 84 Samuel Brun, $S$ Hague, 1913), 38. An Jones, German Source 8 she great quan dagregisters wit het ka Hague, 1953), 37, 158 $124,126$.

Bradbury, Benir

89 Dapper, Bescrij 
charge of trade. ${ }^{79}$ Volume was considerable. Just one of the several Dutch ships involved in the Benin trade, the Olyphant, delivered 88,235 pounds of ivory and 1,337 pounds of Benin pepper to Texel in $1630^{80}$

According to Ryder's study, however, these centrally managed products were no longer being shipped out in such quantity from Benin by the 1640 s. $^{81}$ Mid-seventeenth century Dutch account books reveal that pepper had disappeared as an export and that cloth was very important, ${ }^{82}$ but the cloth trade was not a monopoly of the king. The production of cloth was widespread and in local hands. Cotton growing and weaving were extensive throughout the Benin kingdom, as noted by visitors beginning with Welsh in I 588 , followed by Ulsheimer in $160 \mathrm{I}$, who noted its sale to Europeans through Lagos, then in Benin's hands, and Ruiters in $1602 .{ }^{83}$ Samuel Brun, visiting Benin about 1614 noted that Benin made 'very beautiful cloths, which are exported far and wide and sold '. ${ }^{84}$

Weaving was essentially a home industry, done by women in their spare time, if more recent documentation is any guide. Their cloth was not only for personal use, as the written accounts attest, but for long-distance trade with other African people, thousands of such cloths being shipped annually by the middle of the seventeenth century, either by the inland waterway past Lagos or on European shipping to the Gold Coast. ${ }^{85}$ They even turned up, through European shipping connections, among the burial goods of Queen $\mathrm{Njinga}$ in the interior of central Africa in $1663 .^{86}$

Organization of the external cloth trade was probably in the hands of trading associations to judge from modern fieldwork, which controlled the routes that linked the interior with the coast. ${ }^{87}$ Indeed these associations seem to have been the lowest bureaucratic level mentioned in van Nyendael's description, along with 'intercessors' and 'elders' ${ }^{88}$ Dapper also noted that in Ughoton, 'the king chooses certain royal officials (rijksraad) or merchants (koopman) who alone are allowed to come to the Europeans, and these officials seem to have been tightly controlled by the lower bureaucracy, since he noted that when a ship arrived, the king would be notified and would dispatch 'two or three royal officials with 20 or 30 merchants to travel to the whites to trade' ${ }^{89}$ The Dutch merchant Jacob Jacobszoon granted credit of

78 Nicholaas van Wassenaer, Historisch verhael aller gedenckwaerdiger geschiedenißen die in Europa ... (Amsterdam, I62 $\mathrm{r}-35$ ), 5te Deel, fol. 57v, May 1623 .

${ }^{80}$ Van Wassenaer, Historisch verhael, rgte Deel, fol. 23v, May 1630.

s1 Ryder, Benin and the Europeans, 93 . Note that the absence of the full set of 'Old West India Company" records make any systematic assessment of the volume of Dutch trade very difficult, so this is more or less an impressionistic conclusion.

82 'Aenwÿsinghe', fol. $24 \mathrm{v}-29 \mathrm{v}$.

83 Welsh's account is in Hakluyt, Principal Voyages, mod. ed., 6: 456; Ulsheimer, 'Warhaftte Beschreibung', fol. 56a; Ruiters in de Marees, Beschrijuinge, r 17 a.

${ }^{84}$ Samuel Brun, Schiffarten, Basel, 1624 (mod. ed. by S. P. L'Honoté Naber, The Hague, 1913), 38. An excellent English translation, with original pagination marked, is in Jones, German Sources.

85 The great quantities of Benin cloth can be seen in $K$. Ratelband (ed.), Vijf dagregisters uit het kasteel São Jorge da Mina (Elmina) aan de Goudkust (1645-47) ("The Hague, 1953), 37, I 58; on the general pattern of trade, Dapper, Noukeurige Beschrijvinge, $124,126$. 86 Cavazzi, Istorica Descrizione, Book 6, nos. I 10-12.

87 Bradbury, Benin Studies, 8I.

88 Bosman, Beschyvinge, 227.

${ }^{83}$ Dapper, Bescrijuinge, 125 .

yvinge, $225-6$.

$\mathrm{n}$ the Portuguese period, is (mod. ed.) VI, 459.

yvinge, 227 . 
680 'three or five band' and 'ten hundred four band Benin cloths' to some 'viadors or commanders of the king of Great Benin' in 1610 . These officials, who delivered 379 three-band cloths to another ship the next year, were possibly dealing on their own, clearly in sizable quantity. ${ }^{90}$ These officials probably had to develop systems of relationships with local merchants in order to obtain cloth at the numerous regional markets throughout the kingdom.

Francesco da Monteleone explained in I 692 that 'the cloths are not found ready made, but [the African traders] take goods on credit, and with these goods they have the cloth made in five or, at the most, six months' ${ }^{91}$ The 'viadors' with whom Jacob Jacobszoon dealt in 16 ro were only able to deliver 30 I four-band cloths out of their total trust to him, complaining that the others were 'not yet ready' even though he remained constantly asking about them for a whole month. ${ }^{92}$ The fact that it might take up to half a year to fill an order for cloth indicates that the operations of this mercantile network were more diffuse. ${ }^{93}$ Van Nyendael's description gives us a hint that some commoners in the vicinity of the Dutch trading posts gained in trade on their own, although powerful great officials would seize the goods of any who were too successful. ${ }^{94}$ In all probability it was simply easier to leave considerable day-to-day activity in the hands of private persons and to exercise control in the least instance. Within the system there was a fierce rivalry and, if we can trust Dapper on this score, not a small amount of corruption..$^{95}$

The decentralization of wealth would eventually reflect itself in growing power by groups that could capitalize on the opportunities of the growing external trade, many of which would not have been able to exercise power before. Commercial wealth was probably translated into the ownership of large groups of slaves, who insured continued wealth and might provide a demographic base to assist their owner's political ambitions. Oral traditions of today also suggest concentrations of wealth in the hands of nobles, especially war chiefs like the Ezomo, who accumulated slaves as wealth which they put to work in farms. ${ }^{96}$ This is more or less explicitly noted in 1732 , when the Ezomo refused a Dutch request for a runaway slave, saying the slave was in one of his villages, named Iggie (igue is, in fact, a generic word for a remote village). ${ }^{97}$

These factors might well have put considerable wealth in the hands of the lower members of the administration and the merchants whom they supervised, especially since oversight at higher levels was difficult because of the dispersed nature of the trade. Such a situation would have tended to make the lower levels of administration more powerful, and perhaps aroused the cupidity of their superiors, resulting in the tension between different levels of the associations that was a major factor in the civil war.

90 Gemeentarchief Amsterdam, Notarial Archives, 335, fols. 362-362v, 22 Nov. r6r2.

91 APF: SRC, Congo 2, fol. 585, Francesco da Monteleone to Propaganda Fide, 24 May 1692.

22 Gemeentarchief Amsterdam, Notarial Archive 355, fol. 263, 22 Nov. I6r2.

93 See documentation cited in Ryder, Benin and the Europeans, 93-4 and $129-31$.

94 Bosman, Beschyivinge, 224-25; 'Aenwÿsinghe', fol. I4v.

95 Dapper, Naukeurige Beschrijvinge, 129-31. ${ }^{6}$ Bradbury, Benin Studies, 253.

97 ARA: NBKG, vol. 98, van Essen to Pranger, 22 Feb. 1732, quoted in Ryder, Benin, I 78 . We have not been able to trace the original document.
This growth of less probably drove diss associations, especiall tration. Tradition has the 'street kings' wl Dapper and Nyendar and attributed to hirr. commander he had , rank lacked. As we s] the civil war of the fi military clout to the

The civil war was $\mathrm{f}$ Monteleone in 1696 around $\mathrm{i} 689$ - and $c$ 1730 s. $^{100}$ European Apparently the dest Nyendael took place who visited then, fo even in van Nyenda intact, or at least hac accounts, that centr

Some [officials] ... others over militar There is nothing $\mathrm{b}$ [Versorger]. ${ }^{102}$

These officials see reminiscent of earli Nyendael's day b. indicated by the po records do not men them, when juxta inferences about th Ozuere.

The civil war me time that Ewuakpe I690). ${ }^{104}$ Tradition

Egharevba, Sho

"Dapper, Nauket

100 $\mathrm{APF}$ : SRC, Co

speak of a civil war is

101 APF: SOCG v

102 Bosman, Beschr

104 Bradbury, Beni that the story of $\mathrm{Ak}$ description. Howeve and his brother was APF : SOGC, vol. 6 
Benin cloths' to some in $16 r 0$. These officials, ip the next year, were antity. ${ }^{90}$ These officials ith local merchants in rarkets throughout the

he cloths are not found credit, and with these st, six months'. 91 The vere only able to deliver , complaining that the constantly asking about up to half a year to fill ais mercantile network es us a hint that some gained in trade on their goods of any who were it to leave considerable $d$ to exercise control in e rivalry and, if we can rruption. ${ }^{95}$

eflect itself in growing unities of the growing able to exercise power into the ownership of $a$ and might provide a bitions. Oral traditions the hands of nobles, slaves as wealth which plicitly noted in 1732 , away slave, saying the in fact, a generic word

lth in the hands of the erchants whom they vas difficult because of would have tended to $I$, and perhaps aroused ion between different te civil war.

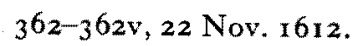
to Propaganda Fide, 24

63,22 Nov. 1612.

ins, $93-4$ and $129-31$.

y, Benin Studies, 253 . , quoted in Ryder, Benin,
This growth of less controlled trade dominated by the lower associations probably drove dissention between different levels of the bureaucratic associations, especially between the Iyase and the Obas and higher administration. Tradition has the Iyase as the head of the town chiefs, undoubtedly the 'street kings' who van Nyendael placed in second rank. ${ }^{98}$ However, Dapper and Nyendael both placed the Iyase outside the main organization and attributed to him considerable authority, ${ }^{92}$ probably because as military commander he had effective power that administrators of higher nominal rank lacked. As we shall see, the Iyase was to be an opponent of the $O b a$ in the civil war of the first half of the eighteenth century who may have given military clout to the wealthy lower administration.

\section{THE CIVIL WAR}

The civil war was first mentioned by the Italian Capuchin Francesco da Monteleone in 1696 as having been going on for some time - probably since around $I 689$ - and continues to appear in other European records until the I 730 s. ${ }^{100}$ European sources do not mention much about the early phases. Apparently the destruction of the city of Benin that was mentioned by van Nyendael took place after 1693 for the Portuguese captain Lourenço Pinto, who visited then, found the city peaceful and prosperous. ${ }^{101}$ Furthermore, even in van Nyendael's day much of the functioning of the bureaucracy was intact, or at least had been so in recent memory, for he records, as did earlier accounts, that centralization reigned at the lower levels:

Some [officials] ... preside over the common people, others over the slaves; yet others over military affairs, over cattle and the products of fields, and so on. There is nothing here that one can think of that does not have its supervisor [Versorger]. ${ }^{102}$

These officials seem to have continued to be appointed in a manner reminiscent of earlier days as well. Posts, he claimed, were obtained in van Nyendael's day by recommendation of the highest officials and were indicated by the possession of a coral necklace as a badge of office. ${ }^{103}$ 'These records do not mention the Obas by name, but the information contained in them, when juxtaposed with oral traditions, enables us to make some inferences about the reigns of $O b a$ Ewuakpe and his sons Akenzua $I$ and Ozuere.

The civil war mentioned by da Monteleone seems to have begun about the time that Ewuakpe succeeded to the throne (Egharevba dates his accession to 1690). ${ }^{104}$ Tradition claims that the Oba Ewuare the Great (mid-fifteenth

${ }_{98}$ Egharevba, Short History, 76 .

${ }^{98}$ Dapper, Naukeurige Beschrijvinge, 129-30; Bosman, Beschryvinge, 225.

100 APF: SRC, Congo 3, fols. 137-8, Francesco da Monteleone, 1696; although these speak of a civil war in Warri and war between Warri and Benin as well.

101 APF: SOCG vol. 517, fol. 308v, Pinto to Propaganda Fide, 28 May 1693.

${ }_{102}$ Bosman, Beschryuinge, 225. 102 Bosman, Beschryuinge, 225.

${ }_{104}$ Bradbury, Benin Studies, 28-29 places the events in the reign of Akenzua, believing that the story of Akenzua's struggle with his brother most closely fitted Nyendael's description. However, Celistino d'Aspra makes it clear that a struggle between an $\mathrm{Oba}$ and his brother was in progress during the period 17 I I-14, or after Nyendael's report, APF: SOGC, vol. 617, fol. I I 5, Celestino d'Aspra letter. 
century) had predicted that if an Oba named Idova ever came to the throne there would be a change in the government, either for bad or for good, and Idova was the given name of Oba Ewuakpe. ${ }^{105}$ The traditions remember that Oba Ewuakpe faced a serious rebellion that arose because he ordered wholesale human sacrifices in honor of his mother at her death. The people rebelled and 'would not attend meetings in his palace, neither would they provide him with food nor supply labor for the upkeep of the royal buildings'. One of the leaders of the rebellion was the then Iyase, Ode, who was to continue his revolt well into the reign of Ewuakpe's son. ${ }^{106}$

According to traditions, until Ewuakpe's reign aristocratic inheritance was governed by the law of atoro, which called for a king to receive all the chief's property upon his death. Such an edict was recorded in Dapper's account, gathered before 1640 :

when a man dies, his widow kept her own property and was given enough for her support and the rest went over to the king, when the eldest son came of age, the king might decide to make the goods over to him. ${ }^{107}$

Another document from the same era makes it clear that even the Osodin, the richest man in all Benin, had been subject to this same stricture when he died in exile, as were all other nobles. ${ }^{108}$

Contemporary documents concur about the rebellion against the $\mathrm{Oba}$ but do not mention problems with inheritance or with sacrifices. Van Nyendael noted that the Oba decided to eliminate certain 'Street Kings' whom he believed to be plotting against him. ${ }^{109}$ Although the $O b a$ was given credit for the action, and no doubt it was carried out in the $\mathrm{Oba}$ 's name, it was probably undertaken by the highest officials, the 'Great Men', with the aim of reducing the Iyase's power and disciplining middle-level administration which had come to support him. But while outsiders may have read its political meaning quite correctly as a struggle over power, the traditional explanation concerning atoro, and ultimately struggles over wealth and inheritance, may have discerned the deeper issues behind the politics.

The $O b a$ and 'Great Men's' attempt to discipline their rebel subordinates backfired, however, and the 'Street King' revolted, left the city and took a large part of the population with him. The $\mathrm{Oba}$ in turn gathered some troops 'from a neighboring country' and attacked the Street King, but was unsuccessful; in retaliation, the Street King returned and thoroughly sacked Benin City, sparing only the $O b a^{\text {'s }}$ palace. ${ }^{110}$

The fact that he had sufficient military power to defeat the $O b a$ and even return to sack the city strongly suggests that the rebel Street King of van Nyendael's day was the Iyase. ${ }^{111}$ Although van Nyendael does not name the rebel Street King, there is good reason to believe that he was Ode, one of the most important Iyases of the period. ${ }^{112}$ This rebel chief appears in Benin oral tradition as a threatening foe and a magician so powerful that he was able to transform himself into an elephant.

105 Egharevba, Short History, 37.

107 Dapper, Beschrijuinge, 124.

108 Bosman, Beschryvinge, 255.

111 Bosman, Beschyivinge, 256.

112 Egharevba, Short History 39. Apparently Akenzua attempted to appoint another Iyase, named Ogbornwan in place of Ode, but was rebuffed.
His legendary associ ivory trade, controlled and, unlike the peppe modern tradition and fi in the hands of a guild just outside the capital diffuse in earlier times located to the northeas trade with the Ishan : Niger River, in turn, $v$ mouth of the river anc and Benue rivers. One river from at least the

The Dutch traded century but then ther of ivory resumed su coincides with the out use the ivory trade $t$ struggle against $\mathrm{Oba} \mathrm{E}$ Iyase (then called the slaves and ivory'. terpretation, as does supported the rebels

After a standoff the mediation with the $\mathrm{Pc}$ Nyendael noted, ho positions to those $\mathrm{w}$ agreed to return. ${ }^{118}$ correlates with oral a conflict by reaching heritance.

Royal tradition rel of his overzealous $m$ finally, was able to inheritance and succ part of the resolutic sometime before 17 rule was different: " he noted, 'the eldes

The traditions $n$ rebellion had defeat win the right to na succession. Ewuakp

113 Egharevba, Conc

11 David Northrup South-Eastern Nigeria 115 Ryder, Benin an 118 ARA: NBKG v William Butler, 20 Jar 117 See documents 118 Bosman, Beschry 
His legendary association with elephants hints at a connection with the ivory trade, controlled by royal officials since the early seventeenth century and, unlike the pepper trade, still important in the mid-century. While modern tradition and fieldwork indicate that the ivory trade was concentrated in the hands of a guild of elephant hunters located in the village of Oregbeni, just outside the capital city, it is clear that the procurement of ivory was more diffuse in earlier times. The home base of the Iyase n'Ode was Ugha village, located to the northeast of Benin City close to Ehor, the marketing center for trade with the Ishan area and, through that, with the Niger River. ${ }^{113}$ The Niger River, in turn, was a major trade axis between the Igbo peoples of the mouth of the river and the Igala to the north of the confluence of the Niger and Benue rivers. One of the major items of trade with Europeans along this river from at least the sixteenth century was ivory. ${ }^{114}$

The Dutch traded extensively in ivory in the first half of the seventeenth century but then there was a period of diminished activity. Their purchases of ivory resumed suddenly and intensively during the $1690 \mathrm{~s},{ }^{115}$ which coincides with the outbreak of the civil war in Benin. Thus Ode was able to use the ivory trade to finance his political ambitions, including the long struggle against $O b a$ Ewuakpe. Much later, when the $O b a$ finally defeated the Iyase (then called the 'under king' [onder Conig]), they took 'as booty many slaves and ivory'. ${ }^{118}$ The capture of ivory certainly strengthens this interpretation, as does the tradition that Ishan, an ivory trading center, supported the rebels for many years. ${ }^{117}$

After a standoff that lasted some ro years (perhaps 1689-99), and through mediation with the Portuguese, the situation was eventually patched up. Van Nyendael noted, however, that the $\mathrm{Oba}$ had to grant amnesty and high positions to those who agreed to return to his service. Not all the rebels agreed to return. ${ }^{118}$ The recounting of royal concessions to former rebels correlates with oral accounts of how Ewuakpe finally succeeded in ending the conflict by reaching an accord with the chiefs regarding aristocratic inheritance.

Royal tradition relates that Ewuakpe, abandoned by his people as a result of his overzealous mourning, searched for a way to restore his power and, finally, was able to reach a pact with the powerful chiefs regarding inheritance and succession. Ewuakpe agreed to revoke the law of atoro as a part of the resolution of the crisis. This revocation apparently took place sometime before 1701 , for by the time that van Nyendael came to Benin the rule was different: 'when any person of condition [ymand van Staet] dies', he noted, 'the eldest son receives the entire inheritance'. ${ }^{119}$

The traditions maintain that Ewuakpe, though recognizing that the rebellion had defeated him, and agreeing to a change in the law of atoro, did win the right to name his own heir, and, even more, to set the rules for succession. Ewuakpe, according to tradition, found a way to end the conflicts

113 Egharevba, Concise Lives of the Famous Iyases (Lagos, 1947), 21.

114 David Northrup, Trade without Rulers: Pre-Colonial Economic Development in South-Eastern Nigeria (Oxford, 1978), 146, 172.

115 Ryder, Benin and the Europeans, 93.

116 ARA: NBKG vol. 88, Elmina Journal, 25 Oct. 1721 ; Jacobos Munnickhoven to William Butler, zo Jan. 172x.

117 See documents and arguments in Ryder, Benin and the Europeans, 163.

118 Bosman, Beschryvinge, 255-6. $\quad{ }^{119}$ Bosman, Beschryvinge, $237^{-8}$. 
brought on by the open (read administratively controlled) succession of the seventeenth century by establishing a single authoritative heir. Benin traditions portray Ewuakpe's innovation as the establishment of the rule of primogeniture, ${ }^{120}$ which appears to have manifested itself in the creation of the title of Edaiken, on heir apparent. Milan Kalous, citing the tradition collected by the British government anthropologist $\mathrm{P}$. Amory Talbot that the Edaiken was 'appointed to the [Uzama n' Ihinron] as an Afhai, or adviser, at the beginning of the eighteenth century', argues that the title itself very probably originated at the same time. ${ }^{121}$ It is therefore not surprising that just as van Nyendael notes the changes in the law of succession for noble property, he also records that succession to the throne was to the eldest son. ${ }^{122}$

The new law seems to have been effective, for it was clearly in effect during the long reign of the eighteenth-century Oba Akengbuda. ${ }^{123}$ The French merchant captain Jean-François Landolphe, who visited Benin several times between 1778 and 1799 , reported witnessing the ceremony in which the heir apparent was designated (and, he makes clear, it was not always the senior son). Landolphe was careful to point out that without this formal ceremony, the crown could pass to outsiders, which was clearly the issue that was at stake for Ewuakpe. ${ }^{124}$

\section{THE EIGHTEENTH CENTURY}

Ewuakpe seems to have settled matters with the rebels by I 701, even though the crisis was hardly over. Affairs appear to have rested there until Ewuakpe died, around 17 IO. In a letter ostensibly written by an unnamed Oba to the Pope, dated 2 November 1710 , he mentioned that his father, who had reigned before him, had wanted to receive missionaries but had to refrain because of 'wars raging in my kingdom'. Now, however, the situation was cleared up and missionary work could proceed. Assuming that his accession was a reasonably recent event, this fits the pattern of events described in van Nyendael, in which the wars were eventually patched up by concessions, which would have fitted in between two attempts at missionary work in 1695 and $1710 . .^{125}$

120 Bradbury, Benin Studies, 39-44 points out the problems in determining rules of royal succession for earlier periods of Benin history. He feels that Ewuakpe's reign seems a 'very late date' for the introduction of primogeniture. It seems more likely that primogeniture has been an ideal in Benin political life, but hardly a reality, for quite some time.

121 Milan Kalous, 'The economic and political structure of the Benin kingdom', Afrika und Übersee, 53 (1969-70), 99. See Talbot, Peoples, III, 281-2.

122 Bosman, Beschryvinge, 238 .

${ }_{123}$ Bradbury, Benin Studies, 26 . Akengbuda is said to have had a particularly long reign which covered most of the second half of the century.

${ }^{124}$ Jean-François Landolphe, Mémoires du Capitaine Landolphe, contenant l'histoire de ses voyages, ed. J. S. Quesné ( 2 vols., Paris, 1823 ) II, 58-9. On this occasion Landolphe met the recognized heir, 'Chiffau', whom Bradbury, Benin Studies, 26-7, identifies as Osifo, the personal name of Oba Obanosa, who succeeded Akengbuda. This is one of the few identifiable names in the entire record of contact with Benin.

${ }_{125}$ Obba, king of Benin to Pope, 2 Nov. 1710, in Salvadorini, Missioni, 299-300. An English translation is in Ryder, Benin and the Europeans, $1_{5}$. Our argument owes much to Ryder's reasoning at $115-9$.
This unnamed $O b a$ was Oba Euwakpe's have violated the ne tradition holds that points to a reopening agreement he had ma installing a friendly 1 hoped to gain conce: from Euwakpe, perh contact with the Po Portuguese merchan

However, Ozuere Akenzua, his elder br Ezomo, and may ha Capuchin missionari newly enthroned Ak against his brother'. the mission eventual

Akenzua's ability alliance with the $E z o$ ancient order of chi rule Benin. If the $E_{z}$ not come into promi backers of the Oba a gratitude for his aic consequence beyon concerned. ${ }^{129}$

Bradbury's study century, this chief li just outside Benin that of the Oba. The to wear a coral-bea (Queen Mother) an thing of a second $m$ not a second monar or control the king

Documentary ev the early eighteent treaties and docun

126 Egharevba, Sho

127 European docu English and Portugue Dutch reports in ARA left no records of ever insights, do not start 128 APF : SOCG vi

129 Egharevba, $S h$ 'Ezomo's ikegobo and published 1961).

131 Treaty printed $316-9$. 
This unnamed $O b a$ seems likely to have been Ozuere, who tradition holds was Oba Euwakpe's second son and thus an usurper whose seizure would have violated the newly won concession of primogeniture. Furthermore, tradition holds that the Iyase, Ode, supported his usurpation. ${ }^{126}$ This all points to a reopening of the civil wars and to a repudiation by Ode of the agreement he had made with Ewuakpe as he sought to reassert his power by installing a friendly Oba. It is possible that Iyase Ode and his ally Ozuere hoped to gain concessions beyond those Ode and his supporters had won from Euwakpe, perhaps buttressed by stronger European support through contact with the Pope, which might have included ivory trade through Portuguese merchants as a benefit. ${ }^{127}$

However, Ozuere did not succeed, for he was quickly overthrown by Akenzua, his elder brother, who was probably now joined in alliance with the Ezomo, and may have had support from the former 'great men'. When Capuchin missionaries arrived in 17 I I they found the Oba, presumably the newly enthroned Akenzua, cool to them, and preoccupied with the 'war against his brother'. The 'great men' of the palace were openly hostile and the mission eventually failed. ${ }^{128}$

Akenzua's ability to defeat Iyase n'Ode seems to have derived from his alliance with the Ezomo, a title which tradition places among the Uzama, the ancient order of chiefs that had originally invited Araminyan to come and rule Benin. If the Ezomo was really an ancient title, however, its holders did not come into prominence until the civil war, when they emerged as the main backers of the $O b a$ and the amply rewarded source of his military success. In gratitude for his aid, Oba Akenzua I made this title hereditary, and as a consequence beyond his control, at least as far as its personnel were concerned. ${ }^{129}$

Bradbury's study of the Ezomo indicates that probably since the eighteenth century, this chief lived in a semi-independent state in the village of Uzebu, just outside Benin City, where he kept a court similar to, but smaller than, that of the Oba. There he had the right to create his own chiefly titles, indeed to wear a coral-bead crown, placing him on a par with the Oba, the Iyoba (Queen Mother) and the Edaiken. ${ }^{130}$ In short, Akenzua had created something of a second monarch in exchange for his victory in the civil wars, or if not a second monarch, then surely a military force that could potentially defy or control the king in times of stress.

Documentary evidence generally confirms the traditions on this point: in the early eighteenth century the Ezomo stood out from other officials in treaties and documents signed with the Dutch. ${ }^{131}$ In his report of 1722 ,

126 Egharevba, Short History, 39.

127 European documentation is unfortunately lacking on this critical period. The English and Portuguese ships that frequented the area and are often mentioned in the later Dutch reports in ARA: NBKG, vols. 81-102, did not have a factor on land and probably left no records of events in the interior, while the Dutch records, which might give some insights, do not start in full until 1715 .

128 APF : SOCG vol. 617, fol. I1 5, Celistino d'Aspra to Propaganda Fide, n.d.

129 Egharevba, Short History, 39; For more details from tradition, see Bradbury, 'Ezomo's ikegobo and the Benin Cult of the Hand', in Benin Studies, 252-5 (article first published 196r). ${ }_{130}$ Bradbury, 'Ezomo's ikegobo', 253.

131 Treaty printed in translation as Appendix III in Ryder, Benin and the Europeans, 3r6-9. 
Munnickhoven, one of the Dutch factors, felt that the Ezomo was in a better position to trade than the $O b a$ himself, perhaps surpassing the $O b a$ in wealth, ${ }^{132}$ suggesting that whatever the title's antiquity, its power may well have been anchored, like those of other administrative officers, on trade. The factor Raems noted after his visit to Benin in 1736 that he went to the 'Captain of War ... this Captain has great authority and does most of the governing of the kingdom' ${ }^{133}$ By 1778 , Landolphe found the Ezomo to be the richest man in the land and a power equivalent to that of the Oba. ${ }^{134}$

Akenzua's reassertion of his prerogatives under the newly reasserted right of primogeniture with the military aid of the Ezomo did not end matters, for the Iyase still had power, even if Ozuere seems to have died shortly after Akenzua's re-establishment. If the Oba's war against his brother ended with Ozuere's death, the war against the Iyase dragged on. In 1716, Michael Heyman, Dutch factor at Ughoton, noted that gum shipments from the interior were blocked and had to reach the coast by a circuitous route, because '[ $t$ ] he war with are de roy [Street King] has closed the road'. ${ }^{135}$

It was no wonder that the Oba jubilantly reported to the Dutch factor Jacobos Munnickhoven on 6 January 1721 that he had recently won a major victory, putting the 'under king' (presumably the same person as the Street King and Iyase $n^{\prime} O d e$ ) to flight and capturing considerable booty, ${ }^{136}$ for it represented the final resolution of his war and the consolidation of his succession and his father's right to appoint a successor. This victory may have turned the tide against an independent Iyase, although reports in 1726 and 1730 still mention wars in the interior, possibly extensions of the civil war or possibly wars of reconquest in which a triumphant $\mathrm{Oba}$ reasserted himself against vassal regions which had taken the opportunity of a preoccupied central power to slip out of Benin's control. ${ }^{13}$ ?

\section{CONCLUSIONS: STRUCTURAL CHANGES IN THE EARLY EIGHTEENTH CENTURY}

Although the Obas of Benin had formally restored the kingdom and won the war against their rivals, they did not control the same sort of state that existed before. One obvious result of the civil war was the shattering of the hierarchically organized bureaucratic associations as a single organization and the establishment of a multi-centered but autonomous set of associations. Unfortunately there are no accounts of Benin structure between the closing of the Dutch factory in 1738 and the arrival of the French sea captain Jean François Landolphe in the last quarter of the eighteenth century. At that time Landolphe observed that there were three classes in Benin: the first

${ }^{132}$ ARA: NBKG, vol, 89, Elmina Journal, 13 May 1722; J. Munnickhoven to W. Butler, 2 Feb. 1722 .

13a ARA: NBKG, vol. 102, Raems to Hertog, 22 Oct. 1736, quoted in Ryder, Benin, 186. We were unable to retrace this reference. 134 Landolphe, Memoires 2: roo-r.

135 ARA: NBKG vol. 83 , Elmina Journal, 14 Dec, i 716 ; Heyman to Robberts 4 Sept. 1716.

138 ARA: NBKG 89, Elmina Journal, 25 Oct. 1721 ; Munnickhoven to Butler, 20 Jan, I 721 .

137 Ryder, Benin and the Europeans, 176 , citing documents in ARA: NBKG 94 and 97 , suggests that the wars of 1726 and 1731 in these texts were continuations the civil war, which is not stated in the documents themselves. being the hommes $g r_{\text {, }}$ earlier fiador/veador) of the first two ranks, Landolphe did not $r$. Osodin, who featured through I735. Ryder is indicative of a sign of the Ezomo. ${ }^{139}$

But other interpre1 were divided into th respectively. These $t$ ] (Iwebo, Ibiwe and Iwi Kings) and the Uzal

The administratio: descriptions and the (Eghaebho n'Ore, or (Eghaebho n'Ogbe or : independent of each of the politics of $B$ interplay between th

In the first half of organization arising , succession, the estab stabilization of impc problems and power centuries. Ultimately conflicts for the mor between rival claima titles hereditary, par the chief in relation about a period of int is, through the reign second quarter to th stability and prospe astation of the civil Stanfield enlisted 0 Ughoton. His acco portrays a thriving

138 Landolphe, Mem 140 Bradbury, Benin

141 Bradbury, in ma Bosman's Description assumption that group certainly erroneous'.

142 As Bradbury po father to eldest son. It Ogbebo and Osemwe contested with each ot he was the rightful he concept of legitimacy Obas to recognize the 
Ezomo was in a better surpassing the $O b a$ in dity, its power may well e officers, on trade. The 36 that he went to the $y$ and does most of the found the Ezomo to be to that of the $O b a .^{134}$ e newly reasserted right did not end matters, for have died shortly after his brother ended with on. In 1716 , Michael m shipments from the by a circuitous route, closed the road'. ${ }^{135}$ ed to the Dutch factor d recently won a major ne person as the Street derable booty, ${ }^{136}$ for it e consolidation of his sor. This victory may though reports in 1726 extensions of the civil nphant $O b a$ reasserted the opportunity of a trol. ${ }^{13}$ ?

\section{THE EARLY}

kingdom and won the ort of state that existed the shattering of the a single organization ous set of associations. e between the closing ench sea captain Jean enth century. At that es in Benin: the first J. Munnickhoven to $W$. quoted in Ryder, Benin, e, Memoires 2: roo-1. iman to Robberts 4 Sept. shoven to Butler, zo Jan. ARA: NBKG 94 and 97 , itinuations the civil war, being the hommes grands, great men, the second phidors (a version of the earlier fiador/veador), and the third passadors. He does not specify the duties of the first two ranks, but describes the passadors primarily as messengers. ${ }^{138}$ Landolphe did not name the three 'great men', the Uwangue, Eribo, and Osodin, who featured so prominently in Dutch accounts from van Nyendael through 1735. Ryder argued that Landolphe's failure to mention these titles is indicative of a significant shift of political power in Benin in the direction of the Ezoma. ${ }^{138}$

But other interpretations are possible. He noted that the hommes grandes were divided into three sections that oversaw commerce, finance and war respectively. These three sections could be subdivisions of the palace chiefs (Iwebo, Ibiwe and Iweguae) or represent the palace and town chiefs (or Street Kings) and the Urama.

The administration of Benin in the nineteenth century, as reflected in descriptions and the oral traditions of today, is one in which the Street Kings (Eghaebho n'Ore, or town chiefs in modern parlance) and the Great Men (Eghaebho $n^{\prime} \mathrm{Og} b e$ or Palace Chiefs in modern parlance) are two associations, independent of each other and directly under control of the kings. ${ }^{140}$ Much of the politics of Benin in the nineteenth century involved a complex interplay between the $O b a$, the Ezomo, and these two associations. ${ }^{141}$

In the first half of the eighteenth century, then, there was a new form of organization arising out of the wars. The development of a clearer mode of succession, the establishment of administrative lines of command, and the stabilization of important titles all can be seen as attempts to resolve the problems and power struggles of the late seventeenth and early eighteenth centuries. Ultimately the establishment of a designated heir would not end conflicts for the monarchy, for the nineteenth century was full of struggles between rival claimants to the status of rightful heir. ${ }^{142}$ Similarly, making titles hereditary, particularly that of the Ezomo only increased the power of the chief in relation to the king. Nevertheless, the reorganization did bring about a period of internal peace that lasted up to the end of the century, that is, through the reign of $\mathrm{Oba}$ Akengbuda. For the Kingdom of Benin from the second quarter to the end of the eighteenth century was a time of political stability and prosperity. Benin had recovered completely from the devastation of the civil wars. In the early 1780 s, the Irishman James Field Stanfield enlisted on a slave ship and spent some time at a factory at Ughoton. His account of Benin (from an avowed anti-slavery stance) portrays a thriving economy and a peaceful country:

\footnotetext{
${ }^{138}$ Landolphe, Memoires II, $60-6 \mathrm{r}$.

140 Bradbury, Benin Studies, 54-74.

141 Bradbury, in making his annotations to this account for the 1967 Cass reprint of Bosman's Description of Guinea, was quick to notice the discrepancy and wrote: 'His assumption that groups of officials were ranked in a single hierarchical series is almost certainly erroneous'.

${ }_{142}$ As Bradbury points out: 'In the later period succession went theoretically from father to eldest son. In fact this principle rarely worked smoothly. In successive reigns Ogbebo and Osemwede, Adolo and Ogbewenkon and Ovoramwe and Orokhorho contested with each other and each was able to claim some justification for the view that he was the rightful heir. The ambiguities that this implies derive from the ill-defined concept of legitimacy in this context and from the apparent unwillingness on the part of Obas to recognize their successors'. Benin Studies, 39.
} 
I never saw a happier race of people than those of the kingdom of Benin. The subjects of the king of Benin were, during my observation there, seated in ease and plenty. The slave trade, and its unavoidably bad effects excepted, everything bore the appearance of friendship, tranquility, and primitive independence. At Gatoe the markets were regular and well stocked: they teemed with luxuries unknown to Europeans. Their fishermen, hunters, and husbandmen, brought in their stores and delicacies: their smiths, carpenters, and weavers, and believe me, there are such among them, displayed their curious manufactures. Fowls, fish, fresh and dried provisions, fruits of the most delicious kind, various sorts of pepper and spices, potatoes, yams, plantains, calavances, cocoa nuts, sugarcane, purslane, calliloo, ocra, palm-wine and palm oil, were in plenty there. These added to native coral, mats of a most curious texture, Benin and Jaboe cloths of beautiful colours, ivory, gold-dust, gums, woods, wax, cotton and other commodities, proved a demonstration the inexhaustible store of valuable articles, which they could substitute for the unnatural traffic in human flesh; and shewed incontestably that they could improve their produce to a state worthy the return of British luxuries. ${ }^{143}$

Labarthe, who accompanied Landolphe in 1790 , found a large and peaceful capital city and a beautifully decorated palace. Wishing to demonstrate his power to the visitors, the $O b a$ (probably Akengbuda) laid out before them a lavish display: 'all the riches of his realm in coral beads' ${ }^{144}$ - a vivid image which stands in sharp contrast to that of his seventeenth century predecessor, $O b a$ Ahenzae, who gambled away all the royal coral beads in games of dice. ${ }^{145}$

Benin's civil war period reveals a complex interplay of royal power and administrative independence, which can only be fully explored by taking into consideration both the written record and the oral traditions. Using these two sources, with care and with proper critical attention shows us that it is possible to get past the static vision of the past left by oral tradition and see a much more dynamic African administrative history than most historians have imagined, for Benin and perhaps for other regions.

${ }^{143}$ James Field Stanfield, Observations on a Voyage to the Coast of Africa (and ed., Edinburgh, 1807 [1788]), 63-4. The authors are grateful to William Hart for providing this reference.

144 Pierre Labarthe, Voyage à la côte de Guinée, ou descriptions des côtes d'Afrique, depuis le Cap Tangrin jusqu'au Cap de Lopez-Gonzalves (Paris, 1803 ), 178.

145 Egharevba, Short History, 34. 